\title{
Menumbuhkan Minat Siswa SD Terhadap Mata Pelajaran Matematika Di SDN 01 Ciduwet Kabupaten Brebes
}

\author{
Siti Maryam Munjiat ${ }^{1 *}$, Anis Syaefunisa ${ }^{2}$ \\ IAIN Syekh Nurjati Cirebon \\ 1e-mail: sitimaryammunjiat@syekhnurjati.ac.id \\ 2e-mail: anissyaefunisa@gmail.com \\ *Corresponding Author
}

\begin{abstract}
ABSTRAK
Latar belakang pengabdian ini adalah rendahnya hasil belajar matematika kelas VI A SD Negeri 01 Ciduwet. Berdasarkan hasil pengabdian, salah satu penyebabnya adalah rendahnya minat belajar siswa. pengabdian ini bertujuan untuk menganalisis minat belajar siswa pada mata pelajaran matematika, mengungkapkan faktor-faktor pendukung dan penghambat minat belajar siswa serta menjelaskan upaya-upaya yang dilakukan guru agar dapat mengatasi faktor yang menghambat minat belajar tersebut. Metode yang digunakan dalam pengabdian ini yaitu dengan bermain peran atau role playing. Subjek dalam pengabdian ini yaitu kelas VI A yang berjumlah 20 orang. Alat pengumpulan data yang digunakan dalam pengabdian ini yaitu lembar observasi, lembar wawancara, dan dokumentasi. Hasil pengabdian menunjukkan bahwa minat belajar siswa pada mata pelajaran matematika kelas VI A SDN 01 Ciduwet berada pada kategori baik dengan rata-rata hasil observasi sebesar 71,50\%. Faktor pendukung minat belajar siswa adalah motivasi belajar siswa, adanya arahan dan dorongan belajar yang diberikan oleh guru, lingkungan belajar yang tenang, dan perlelngkapan belajar yang lengkap. Faktor penghambat minat belajar siswa yaitu kondisi kelas ramai, siswa sibuk sendiri saat guru menjelaskan materi, siswa tidak memiliki kesiapan untuk belajar, dan perlengkapan pembelajarannya yang tidak lengkap. Upaya guru dengan memberikan motivasi siswa saat pelajaran akan dimuli dan arahan pada saat pembelajaran berlangsung.
\end{abstract}

Kata Kunci: Minat Belajar, Matematika, Siswa

\begin{abstract}
The background of this dedication is the low learning outcomes of mathematics class VI A SD Negeri 01 Ciduwet. Based on the results of dedication, one of the causes is the low student interest in learning. This service aims to analyze student interest in learning mathematics, reveal supporting factors and inhibitors of student interest in learning and explain the efforts made by teachers in order to overcome the factors that inhibit learning interest. The method used in this service is to play a role or role playing. The subject in this service is class VI A, amounting to 20 people. Data collection tools used in this service are observation sheets, interview sheets, and documentation. The results of the dedication show that students' interest in learning mathematics in class VI A SDN 01 Ciduwet is in the good category with an average observation result of $71.50 \%$. Supporting factors for student learning interest are student learning motivation, the direction and encouragement of learning provided by the teacher, a quiet learning environment, and complete learning equipment. Factors inhibiting student interest in learning are crowded class conditions, students busy themselves when the teacher explains the material, students do not have readiness to learn, and learning equipment is incomplete. The teacher's efforts by motivating students when the lesson will start and direction when learning takes place.
\end{abstract}




\section{PENDAHULUAN}

Pendidikan merupakan suatu hal yang sangat penting dalam kehidupan manusia. Pendidikan merupakan suatu proses yang didalamnya terkandung banyak aspek yang saling berkaitan dan ketergantungan satu dengan yang lainnya. Selain itu, pendidikan merupakan usaha sadar untuk menyiapkan peserta didik melalui kegiatan bimbingan, pengajaran, dan latihan bagi peranannya di masa yang akan datang (Susandi A. D. \& Widyawati, 2017). Aspek tersebut terdiri dari tujuan yang hendak dicapai, peserta didik yang belajar, guru yang mengajar, materi yang disampaikan, model yang digunakan, dan evaluasi untuk mengukur keberhasilan kegiatan belajar mengajar tersebut.

Pendidikan berfungsi mengembangkan kemampuan dalam membentuk perilaku serta mencetak manusia pada peradaban bangsa yang bermartabat dalam rangka mencerdaskan kehidupan bangsa, Pendidikan juga bertujuan untuk mengembangkan potensi peserta didik agar menjadi manusia yang memiliki iman dan takwa kepada Tuhan Yang Maha Esa, berakhlak mulia, sehat, berilmu, cakap, kreatif, mandiri, dan mampu menjadi warga negara yang demokratis serta bertanggung jawab (Widyaningrum, 2016). Berdasarkan tujuan tersebut, pendidikan memegang peranan penting dalam upaya mencerdaskan kehidupan bangsa dan mengembangkan manusia Indonesia seutuhnya. Pendidikan dalam setiap disiplin ilmu membantu siswa untuk berfikir. Pendidikan harus membantu siswa bertanggung jawab terhadap pemikirannya. Walaupun tujuan ini tersirat dalam setiap disiplin ilmu, tujuan ini lebih cocok untuk pendidikan matematika karena matematika adalah suatu disiplin dimana seoranganak dapat menyelesaikan suatu problem dan mempunyai kepercayaan diri bahwa apa yang dilakukannya adalah benar, tetapi karena logika yang sangat jelas dalam penyelesaian itu.

Pembelajaran matematika sendiri memiliki beberapa tujuan. Tujuan dari pembelajaran matematika (Depdiknas, 2006) adalah agar siswa memiliki kemampuan (1) konsep matematika, adalah menjelaskan keterkaitan antara konsep satu dengan yang lainya dan mengaplikasikan pada konsep algoritma, secara luwes, akurat, efisien, dan tepat, dalam pemecahan masalah. (2) Pola penalaran dan mampu melakukan manipulasi matematika dalam membuat generalisasi, menyusun bukti, atau menjelaskan gagasan dan pernyataan matematika. (3) Memecahkan masalah dan kemampuan memahami masalah, merancang model matematika, menyelesaikan model dan merangcang solusi yang diperoleh. (4) Menginformasikan gagasan dengan beberapa output seperti simbol, tabel, diagram, atau media lain. (5) Menghargai kegunaan matematika dalam kehidupan, yaitu memiliki rasa ingin tahu, perhatian, minat dalam mempelajari matematika, serta sikap ulet dan percaya diri dalam pemecahan masalah. 
Minat sangatlah berpengaruh besar terhadap belajar, karena bila bahan pelajaran yang dipelajari tidak sesuai dengan minat siswa, siswa tidak akan belajar dengan sebaik-baiknya, karena tidak ada daya tarik bagi siswa untuk belajar. Wardiana dalam (Rusmiati, 2017) menyatakan bahwa siswa yang memiliki minat belajar tinggi akan melakukan kegiatan lebih banyak dan lebih cepat, dibandingkan dengan siswa yang kurang termotivasi dalam belajar. Menurut Djamarah dalam Djamarah dalam (Fauziah, 2017) menyatakan bahwa minat senantiasa berpindah-pindah namun demikian ia menghendaki keaktifan. Ia kerap kali mendasarkan kegiatan-kegiatannya atas pilihannya sendiri dan dapat lebih suka mengusahakan sesuatu tertentu dari pada yang lainnya.

Berdasarkan hasil pengabdian di SDN 01 Ciduwet pada mata pelajaran Matematika kelas VI A beberapa waktu lalu pada tanggal 06 Agustus 2019, bahwa ada beberapa siswa kelas VI A yang mengalami masalah dalam minat belajar. Hal tersebut dapat dilihat dari hasil belajar berupa nilai ulangan harian siswa, dilihat dari aktivitas didalam kelas pada saat pembelajaran berlangsung berdasarkan hasil pengamatan siswa kurang memperhatikan penjelasan guru pada saat pembelajaran berlangsung, serta kurangnya perhatian dan minat belajar siswa pada saat proses belajar dan pembelajaran berlangsung.

Minat salah satu faktor internal, mempunyai peranan dalam menunjang hasil belajar siswa. siswa yang tidak berminat terhadap bahan pelajaran ditandai dengan sikap yang kurang simpatik, tidak konsetrasi dan kurang bergairah mengikuti proses belajar. Minat memiliki peranan yang sangat penting dalam kehidupan siswa dan mempunyai dampak yang besar terhadap kegiatan belajar memiliki usaha yang lebih baik. Minat merupakan sesuatu yang lahir dari seseorang atau gairah seseorang yang menyebabkan orang tersebut menggunakan waktu, biaya dan tenaga untuk kesukaannya terhadap obyek itu (Maonde, 2010). Siswa yang memiliki minat pada mata pelajaran tertentu atau kegiatan tertentu akan berusaha lebih baik dibandingkan siswa yang kurang memiliki minat pada pelajaran tersebut. Menurut Djamarah dalam (Fauziah, 2017) menyatakan bahwa minat senantiasa berubah dan dinamis namun demikian ia menghendaki keaktifan. Ia kerap kali mendasarkan kegiatan-kegiatan atas pilihannya sendiri dan dapat lebih suka mengusahakan sesuatu tertentu dari pada yang lainnya. Minat merupakan sikap ketertarikan atau sepenuhnya terlibat dengan suatu kegiatan karena menyadari pentingnya dan bernilainya kegiatan tersebut (Sudarsono, 2002). Minat adalah kecenderungan yang tetap untuk memperhatikan dan mengenang beberapa kegiatan. Kegiatan yang diminati seseorang, diperhatikan terus menerus yang disertai rasa senang (Slameto, 2010).

Menurut Purwanto dalam (Rusmiati, 2017) mengatakan bahwa belajar merupakan suatu perubahan dalam tingkah laku dimana perubahan dalam tingkah laku lebih baik, tetapi juga ada kemungkinan mengarah kepada tingkah laku lebih buruk. Secara umum belajar dipengaruhi oleh 
tiga faktor yaitu, (1) faktor dari dalam yaitu faktor-faktor yang dapat mempengaruhi belajar yang berasal dari siswa yang sedang belajar. (2) faktor dari luar yaitu faktor-faktor yang berasal dari luar siswa yang mempengaruhi proses dan hasil belajar. (3) faktor instrumentasl yaitu faktor yang adanya dan penggunaannya dirancang sesuai dengan hasil yang diharapkan. Faktor instrumen ini antara lain : kurikulum, struktur program, sarana dan prasarana, serta guru. Dalam faktor intern terdapat faktor psikologis seperti minat siswa.

Minat belajar adalah salah satu bentuk keaktifan seseorang yang mendorong untuk melakukan serangkaian kegiatan jiwa dan raga untuk memperoleh suatu perubahan tingkah laku sebagai hasil dari pengalaman individu dalam interaksi dalam lingkungannya yang menyangkut kognitif, afektif, dan psikomotorik. Beberapa ahli pendidikan berpendapat bahwa hal yang efektif untuk menumbuhkan minat pada suatu kegiatan baru adalah dengan menggunakan minat dan keinginan siswa (Slameto, 2003). Sedangkan (Klassen; Meilani, 2017) menyatakan bahwa minat belajar merupakan keinginan dan keterlibatan yang disengaja dalam aktivitas kognitif yang memainkan bagian penting dalam proses pembelajaran, menentuan bagiap apa yang kita pilih untuk belajar, dan seberapa baik kitamempelajari iformasi yang diberikan. Jadi dapat disimpulkan bahwa minat belajar adalah pilihan kesenangan dalam melakukan kegiatan dan dapat membangkitkan gairah seseorang untuk memenuhi kesediaannya dalam belajar. Minat belajar adalah kecenderungan perhatian dan kesenangan dalam beraktivitas, yang meliputi jiwa dan raga untuk menuju perkembangan manusia seutuhnya, yang menyangkut cipta, rasa, karsa, kognitif, afektif dan psikomotor lahir batin (Wijaya, 2001).

Menurut Hidayat dalam (Pratiwi, 2015) membagi ketiga unsur minat tersebut menjadi beberapa indikator yang menentukan minat seseorang terhadap sesuatu, antara lain yaitu : pertama, keinginan. Kedua, perasaan senang. Ketiga, perhatian. Keempat, perasaan tertarik. Kelima, giat belajar. Keenam, mengerjakan tugas dan kedelapan mentaati peraturan. Menurut (Slameto, 2003) siswa yang berminat dalam belajar mempunyai ciri-ciri sebagai berikut: (a) Memiliki kecenderungan untuk memperhatikan dan mengenang sesuatu yang dipelajari secara terus menerus. (b) Memiliki rasa suka dan senang pada sesuatu yang diminati. (c) Mendapatkan suatu kepuasan pada sesuatu yang diminati. Ada minat dan tertarik pada aktivitas-aktivitas yang diminati. (d) Menyukai yang menjadi minatnya daripada yang lainnya dilakukan melalui partisipasi pada aktivitas dan kegiatan.

Menurut (Ali, 2004) secara keseluruhan ada dua kelompok besar, faktor eksternal (faktor yang berasal dari luar diri siswa) dan faktor internal (faktor yang berasal dari dalam diri siswa). Ada beberapa pengertian faktor eksternal dan internal menurut Sumadi Suryabrata diantaranya sebagai berikut: 


\section{Faktor Internal}

Faktor internal adalah sesuatu yang membuat siswa berminat, yang berasal dari dalam diri sendiri. Faktor internal tersebut antara lain: pemusatan perhatian, keingintahuan, motivasi, dan kebutuhan (Suryabrata, 2010). Perhatian dalam belajar yaitu pemusatan atau konsentrasi dari seluruh aktivitas seseorang yang ditujukan kepada sesuatu atau sekumpulan objek belajar.

a. Keingintahuan adalah perasaan atau sikap yang kuat untuk mengetahui sesuatu; dorongan kuat untuk mengetahui lebih banyak tentang sesuatu.

b. Kebutuhan (motif) yaitu keadaan dalam diri pribadi seorang siswa yang mendorongnya untuk melakukan aktivitas-aktivitas tertentu guna mencapai suatu tujuan.

c. Motivasi adalah perubahan energi dalam diri seseorang yang ditandai dengan timbulnya perasaan dan reaksi untuk mencapai tujuan.

\section{Faktor Eksternal}

Faktor eksternal adalah sesuatu yang membuat siswa berminat yang datangnya dari luar diri, seperti: dorongan dari orang tua, dorongan dari guru, tersedianya prasarana dan sarana atau fasilitas, dan keadaan lingkungan.

Matematika menurut (Abdurrahman, 2003) adalah bahasa simbolis yang fungsi praktisnya untuk mengekspresikan hubungan-hubungan kuantitatif dan keruangan sehingga fungsi teoritisnya adalah untuk memudahkan berfikir. Matematika salah satu mata pelajaran yang diajarkan di sekolah dasar mempunyai posisi yang sangat penting, sebab dasar mempunyai posisi yang sangat penting, sebab disamping dapat memberi bekal kemampuan berhitung, juga dapat memberi bekal kemampuan menalar. Matematika sebagai salah satu ilmu dasar mempunyai peranan yang penting dalam berbagai bidang kehidupan, misalnya dapat dilihat dari banyaknya konsep-konsep matematika yang dapat digunakan baik dalam pengembangan ilmu pengetahuan dan teknologi maupun dalam kehidupan masyarakat sehari-hari. Menurut (Daryanto B., Bakhtiar Usodo, 2015) matematika perlu diberikan kepada semua peserta didik mulai dari sekolah dasaruntuk membekali mereka berpikir logis, analitis, sistematis, kritis, dan kreatif serta mampu bekerja sama. Artinya pembelajaran matematika di sekolah merupakan salah satu komponen pendidikan yang tidak hanya mengembangkan kemampuan dan keterampilan menerapkan matematika, melainkan mengembangkan kemampuan dalam memecahkan masalah yang berhubungan dengan matematika. Oleh karena itu, cara untuk mengembangkan kemampuan matematika siswa adalah dengan memposisikan siswa sebagai individu yang aktif dalam mengkonstruksikan pengetahuan melalui proses belajar yang interaktif. Menurut (Jujun S., 2009) bahwa matematika pada garis besarnya merupakan pengetahuan yang disusun secara konsisten berdasarkan logika deduktif. Logika deduktif merupakan pola berpikir logika dari hal umum menjadi khusus. 
Menurut Cobb dalam (Suherman, 2003) pembelajaran matematika sebagai proses pembelajaran yang melibatkan siswa secara aktif mengkonstruksi pengetahuan matematika. Menurut (Rahayu, 2007) hakikat pembelajaran matematika adalah proses yang sengaja dirancang dengan tujuan untuk menciptakan suasana lingkungan yang memungkinkan seseorang (si pelajar) melaksanakan kegiatan belajar matematika dan pembelajaran matematika harus memberikan peluang kepada siswa untuk berusaha dan mencari pengalaman tentang matematika.

\section{BAHAN DAN METODE}

Metode adalah cara yang digunakan untuk mengimplementasikan rencana yang sudah disusun dalam kegiatan nyata agar tujuan yang telah disusun tercapai secara optimal. Ini berarti metode digunakan untuk merealisasikan proses belajar mengajar yang telah ditetapkan (Sanjaya, 2008).

Proses belajar memerlukan metode-metode khusus yang jelas untuk mencapai tujuan pembelajaran yang efektif dan efisien. Metodologi pembelajaran merupakan cara cara dalam melakukan aktivitas antara pendidik dan peserta didik ketika berinteraksi dalam proses belajar. Pendidik perlu mengetahui dan mempelajari metode pengajaran agar dapat menyampaian materi dan dimengerti dengan baik oleh peserta didik. Metode pengajaran dipraktekkan pada saat mengajar dan dibuat semenarik mungkin agar peserta didik mendapat pengetahuan dengan efektif dan efisien.

Sedangkan metode pembelajaran menurut Abdurrahman Ginting dapat diartikan cara atau pola yang khas dalam memanfaatkan berbagai prinsip dasar pendidikan serta berbagai teknik dan sumberdaya terkait lainnya agar terjadi proses pemblajaran pada diri pembelajar (Ginting, 2008).

Untuk meningkatkan motivasi pembelajaran pada mata pelajaran matematika di SD, metode yang digunakan adalah Bermain peran, yaitu suatu penguasaan bahan pelajaran melalui pengembangan imajinasi dan penghayatan peserta didik yang dilakukan dengan memerankan diri sebagai tohoh hidup atau benda mati. Metode bermain peran merupakan suatu metode yang memperlakukan peserta didik sebagai subjek pembelajaran, dimana peserta didik dengan aktif melakukan praktik-praktik berbahasa, berinteraksi, bertanya dan menjawab dalam tema tertentu yang telah ditetapkan. Belajar akan lebih efektif jika pembelajaran yang diselenggarakn tersebut berpusat pada diri peserta didik. Jika sesuatu dikerjakan secara langsung atau dialami langsung maka pengetahuan yang diperoleh peserta didik akan lebih lama tersimpan pada ingatan mereka. Penerapan pembelajaran dengan metode bermain peran pada mata pelajaran Ilmu Pengetahuan Sosial, ini sesuai dengan prinsip-prinsip pengembangan Kurikulum Tingkat Satuan Pendidikan 
(Huda, 2013) pada jurnal e-Journal Program Pascasarjana Universitas Pendidikan Ganesha Program Studi Pendidikan Dasar (Volume 4 Tahun 2014).

Lokasi penelitian ini dilakukan di SDN 01 Ciduwet, yang terletak di Kecamatan Ketanggungan Kabupaten Brebes. Subjek yang diteliti pada penelitian ini ialah siswa kelas VI A Sekolah Dasar Negeri 01 Ciduwet Kecamatan Ketanggungan Kabupaten Brebes yang berjumlah 20 orang siswa terdiri dari 8 laki-laki dan 12 siswi perempuan, selain itu guru kelas VI A juga menjadi subjek penelitian. Sumber data dalam penelitian ini ada 2 yaitu : primer dan sekunder. Sumber data primer dalam penelitian ini adalah guru matapelajaran Matematika dan siswa Kelas VI A Sekolah Dasar Negeri 01 Ciduwet. Dalam penelitian ini sumber data sekunder ialah dokumentasi.

Teknik pengumpulan data yaitu, teknik observasi, teknik wawancara siswa, teknik wawancara guru dan dokumentasi. Alat pengumpulan data yaitu, lembar observasi, lembar wawancara siswa, lembar wawancara guru, dan dokumentasi.

\section{HASIL DAN PEMBAHASAN}

\section{Hasil}

Hasil observasi minat belajar siswa di kelas VI A SDN 01 Ciduwet pada mata pelajaran matematika diperolehlah hasil

Tabel 1 Hasil Observasi Minat Belajar Siswa

\begin{tabular}{cc}
\hline Total Skor & 185 \\
\hline Rata-rata & 12.50 \\
\hline Persentase & $71,50 \%$ \\
\hline Sumber Data Siswa VI A & SDN 01 Ciduwet Brebes
\end{tabular}

Hasil observasi mendapatkan hasil persentase sebesar 71,50\%, dapat dilihat dari aspek yang diamati ada 10 item. Dimana aspek yang pertama siswa datang tepat waktu kesekolah, terlihat hanya tujuh belas orang siswa yang datang tepat waktu ke sekolah dan tiga orang siswa tidak tepat waktu, hal ini menyatakan bahwa siswa sudah mulai memiliki minat belajar dalam pembelajaran. Aspek yang kedua siswa masuk kelas dengan tertib dan sikap bersahabat dengan sesama teman sekelas, terlihat hanya tujuh belas orang siswa yang masuk kelas dengan tertib dan sikap bersahabat dengan sesama teman sekelas dan tiga orang siswa yang tidak masuk kelas dengan tertib, hal tersebut menyatakan bahwa lebih banyak siswa yang mentaati peraturan di kelas. Aspek yang ketiga siswa memperhatikan guru menjelaskan materi pelajaran matematika dengan tenang, terlihat hanya tiga belas orang siswa yang memperhatikan guru menjelaskan materi pelajaran matematika dengan tenang dan tujuh orang siswa yang tidak memperhatikan guru menjelaskan 
materi pelajaran matematika dengan tenang, hal ini menyatakan bahwa sebagian siswa sudah menyadari pentingnya mendengarkan penjelasan yang guru berikan.

Aspek yang keempat siswa tampak aktif mengikuti pelajaran dan memiliki sikap sopan selama pelajaran berlangsung, terlihat hanya lima belas orang siswa yang tampak aktif mengikuti pelajaran dan memiliki sikap sopan selama pelajaran berlangsung dan ada lima orang siswa yang tampak tidak aktif mengikuti pelajaran dan memiliki sikap sopan selama pelajaran berlangsung, hal ini menyatakan bahwa sebagian besar siswa aktif mengikuti pelajaran di dalam kelas. Aspek yang kelima siswa memiliki sikap senang terhadap materi pelajaran dan perasaan suka terhadap guru mata pelajaran matematik, terlihat hanya sembilan orang siswa yang memiliki sikap senang terhadap materi pelajaran dan perasaan siswa suka terhadap guru mata pelajaran matematika dan ada sebelas orang yang tidak memiliki sikap senang terhadap materi pelajaran dan perasaan suka terhadap guru mata pelajaran matematika, hal ini menyatakan bahwa hampir sebagian siswa tidak begitu menyukai pelajaran matematika. Aspek yang keenam siswa menghargai guru yang sedang menjelaskan materi pelajaran matematika, terlihat hanya lima belas orang siswa yang menghargai guru yang sedang menjelaskan materi pelajaran matematika dan ada enam orang siswa yang tidak menghargai guru yang sedang menjelaskan materi pelajaran matematika, hal ini menyatakan bahwa siswa memiliki perhatian khusus terhadap guru yang mengajar terlihat dari cara mereka menghargai guru yang menjelaskan materi pelajaran matematika di depan kelas. Aspek yang ketujuh siswa berani maju kedepan ketika guru memanggil mengerjakan soal matematika dipapan tulis, terlihat hanya tiga belas orang siswa yang berani maju kedepan ketika memanggil mengerjakan soal matematika dipapan tulis dan ada tujuh orang siswa yang tidak berani maju kedepan ketika guru memaggil mengerjakan soal matematika dipapan tulis, hal ini menyatakan sebagian siswa sudah memiliki rasa percaya diri dalam dirinya terlihat keberaniannya ketika maju kedepan pada saat guru memanggil untuk mengerjakan soal yang telah guru siapkan.

Sedangkan aspek yang kedelapan siswa selalu tepat waktu mengerjakan dan mengumpulkan tugas yang diberikan guru, terlihat hanya lima belas orang siswa yang selalu tepat waktu mengerjakan dan mengumpulkan tugas yang diberikan oleh guru dan ada lima orang siswa yang tidak tepat waktu mengerjakan dan mengumpulkan tugas yang diberikan oleh guru, hal ini menyatakan bahwa sebagian besar siswa sudah mengerti tentang pelajaran matematika yang dijelaskan oleh guru pada saat belajar mengajar berlangsung. Aspek yang kesembilan siswa memiliki minat yang tinggi terhadap pelajaran, terlihat hanya tiga belas orang siswa yang memiliki minat yang tinggi terhadap pelajaran dan ada tujuh orang siswa yang tidak memiliki minat yang tinggi terhadap pelajaran, hal ini menyatakan bahwa masih ada siswa yang kurang memiliki minat terhadap pelajaran matematika. Aspek yang kesepuluh siswa memiliki sikap antusias menerima 
materi pelajaran, terlihat hanya empat belas orang siswa yang memiliki sikap antusias menerima materi pelajaran dan enam orang siswa yang tidak memiliki sikap antusias menerima materi pelajaran, hal ini menyatakan siswa di kelas VI A memiliki sikap yang baik terhadap materi pelajaran terkhusus mata pelajaran matematika.

Berdasarkan dari uraian hasil observasi yang dilakukan, maka dapat disimpulkan bahwa minat belajar siswa pada mata pelajaran matematika dikelas VI A SDN 01 Ciduwet diperoleh persentasi sebesar 71,50 \% dan dapat dikategorika "kuat". Bahwa seluruh siswa memiliki keinginan untuk belajar saat guru menjelaskan materi pelajaran didepan kelas, siswa juga memiliki perasaan senang saat belajar metematika, dengan adanya perhatian yang baik saat pelajaran dimulai, maka siswa cenderung memiliki perasaan tertarik terhadap materi pelajaran yang disampaikan oleh guru, hal tersebut yang mendorong siswa untuk selalu giat belajar serta mengerjakan tugas yang diberikan oleh guru salah satu yang dapat dilakukan oleh siswa adalah dengan mentaati peraturan-peraturan yang ada didalam kelas pada saat proses pembelajaran berlangsung khususnya pelajaran matematika materi menghitung luas bangun datar.

\section{Pembahasan}

Berdasarkan hasil observasi yang dilakukan oleh observer terhadap seluruh siswa kelas VI A tersebut maka diperoleh persentase hasil observasi sebesar 71,50\%. Dilihat dari hasil tersebut siswa siswi kelas VI A SDN 01 Ciduwet memiliki minat belajar yang kuat terutama dalam mata pelajaran matematika. Seluruh siswa memiliki keinginan untuk belajar saat guru menjelaskan materi pelajaran di depan kelas, siswa juga memiliki perasaan senang saat belajar matematika, menurut (Sukardi, 2011) menyatakan bahwa minat merupakan suatu kesukaan, kegemaran atau kesenangan akan sesuatu. Sedangkan menurut Hadi dalam (Nurhasanah, 2016) menyatakan bahwa minat mempengaruhi tiga aspek penting dalam pengetahuan seseorang yaitu perhatian, tujuan dan tingkat pembelajaran.

Berdasarkan hasil wawancara peneliti dengan siswa kelas VI A SDN 01 Ciduwet, adapun beberapa faktor pendukung minat belajar siswa dalam penelitian ini adalah dari guru, siswa, lingkungan dan ketersediaan perlengkapan belajar. Hasil wawancara siswa yang dilakukan peneliti adalah ada siswa yang belum memiliki minat dalam belajar pada saat guru menjelaskan yaitu karena disebabkan adanya gangguan dari teman sekelas terutama teman sebangku yang selalu mengajak mengobrol dan ribut.

Selain faktor pendukung ada juga faktor penghambat minat belajar siswa dalam proses pembelajaran. Berdasarkan hasil wawancara peneliti dengan siswa kelas VI A SDN 01 Ciduwet, ditemukan beberapa faktor yang menjadi penghambat terhadap minat belajar yaitu guru, siswa, lingkungan belajar dan perlengkapan belajar. 
Berdasarkan wawancara guru kelas VI A SDN 01 Ciduwet, yaitu guru melakukan berbagai teknik dalam penyampaian pembelajaran. Seperti guru menggunakan metode yang menarik dalam penyampaian materi. Kemudian guru memberikan motivasi dan dorongan serta arahan kepada siswa yang tidak bisa memperhatikan pembelajaran dengan baik. Selain itu juga guru selalu mengarahkan siswa untuk menyiapkan perlengkapan belajar sebelum pembelajaran dimulai, hal itu dilakukan dengan tujuan agar setelah proses belajar mengajar dimulai tidak ada lagi siswa yang sibuk untuk meminjam pulpen, buku, dll.

\section{KESIMPULAN DAN SARAN}

Adapun kesimpulan dari penelitian ini adalah minat belajar siswa kelas VI A SDN 01 Ciduwet dalam mempelajari matematika tergolong dalam kategori kuat dengan persentase $71,50 \%$.

Faktor pendukung minat belajar matematika siswa kelas VI A SDN 01 Ciduwet adalah dari guru memberikan dukungan dan motivai kepada siswa, siswa aktif mengikuti pelajaran didalam kelas, lingkungan yang tenang dan ketersediaan perlengkapan belajar yang lengkap seperti buku tulis, pilpen dan buku paket. Sedangkan faktor penghambat minat belajar matematika siswa kelas VI A SDN 01 Ciduwet adalah dari guru menjelaskan materi secara monoton dan penjelasan materi pelajaran tidak menarik perhatian siswa, siswa malas belajar, suka mengobrol dan cepat bosan, lingkungan belajar yang ramai akan membuat siswa mengalami kesulitan pada saat mendengarkan penjelasan guru dan perlengkapan belajar siswa seperti alat belajarnya akan menggangu temannya karena meminjam alat tulis dengan temannya serta siswa yang tidak lengkap alat belajarnya cenderung akan mengganggu siswa yang lainnya.

Upaya yang dilakukan guru untuk mengatasi faktor penghambat minat belajar matematika siswa kelas VI A SDN 01 Ciduwet adalah guru memberikan motivasi kepada siswa dengan memberikan pujian kepada siswa pada saat siswa dapat menjawab pertanyaan dengan benar serta guru juga memberikan dorongan kepada siswa yang masih takut dan tidak percaya diri pada saat menjawabpertanyaan. Selain itu, guru juga selalu mengarahkan siswa untuk menyiapkan perlengkapan belajar sebelum pembelajaran dimulai.

\section{UCAPAN TERIMA KASIH}

Terima kasih penulis ucapkan kepada semua pihak yang membantu kegiatan pengabdian (KKN) ini, khususnya kepada Kepala Sekolah, Guru-guru, dan para siswa SDN 01 Ciduwet Brebes yang telah memberi kesempatan untuk melakukan pengabdian. Dan ucapan terima kasih 
juga kepada IAIN Syekh Nurjati Cirebon yang telah memberikan fasilitas dalam kegiatan pengabdian ini.

\section{DAFTAR PUSTAKA}

Abdurrahman, M. (2003). Pendidikan Bagi Anak Berkesulitan Belajar. Jakarta: Rineka Cipta. Ali, M. (2004). Guru dalam Proses Belajar Mengajar. Bandung: Sinar Baru Algensindo.

Daryanto B., Bakhtiar Usodo. (2015). Eksperimen Model Pembelajaran Koperatif Tipe Think Pair Share (TPS) dengan Problem Posing Pada Pokok Bahasan Peluang Ditinjau dari Adversity Quotient (AQ) Siswa Kelas XI SMK di Kabupaten Boyolali Tahun Ajaran 2013/2014. Jurnal Elektronik Pembelajaran Matematika, 1128.

Depdiknas. (2006). Kurikulum Tingkat Satuan Pendidikan (KTSP). Jakarta: Depdiknas.

Fauziah. (2017). Hubungan antara motivasi belajar dengan minat belajar siswak kelas IV SDN. JPSD, 4(1), 49.

Ginting, A. (2008). Esensi Praktis Belajar dan Pembelajaran. Bandung: Humaniora.

Huda, M. (2013). Model-model Pengajaran dan Pembelajaran. Yogyakarta : Pustaka Pelajar. Jujun S., S. (2009). Filsafat Ilmu (Sebuah Pengantar Populer). Jakarta: Pustaka Sinar Harapan.

Klassen; Meilani. (2017). Impak Minat dan Motivasi Belajar terhadap Hasil Belajar Siswa. Jurnal Pendidikan, 1(1), 82.

Maonde, F. (2010). pengaruh kovariat minat dan pengetahuan dasar siswa terhadap hasil belajar matematika. matematika 1, 57.

Nurhasanah. (2016). Minat sebagai Determinan Hasil Belajar Siswa. Jurnal Pendidikan, 1(1), 135 142.

Rahayu. (2007). Tanya Jawab Manajemen Pemasaran Kontemporer. Jakarta: Havarindo.

Rusmiati. (2017). Pengaruh Minat Belajar Terhadap Prestasi Belajar Bidang Studi Ekonomi Siswa MA Al-Fattah Sumbermulyo. Jurnal Ilmiah Pendidikan dan Ekonomi, 1(1), 21-36.

Sanjaya, W. (2008). Perencanaan dan desain sistem pembelajaran. Jakarta: Prenada Media Group.

Slameto. (2003). Belajar dan Faktor-faktor yang Mempengaruhinya. Jakarta: Rineka Cipta. Slameto. (2010). Belajar dan Faktor-faktor yang Mempengaruhinya. Jakarta: Rineka Cipta. Sudarsono, j. (2002). sistem pendidikan nasional 2003. Jakarta: Rineka Cipta.

Suherman. Eman. (2003). Evaluasi Pembelajaran Matematika. Bandung: JIca UPI.Sukardi. (2011). Metodologi Penelitian Pendidikan. Yogyakarta: PT. Elex Media Computindo. Suryabrata, S. (2002). Psikologi Pendidikan. Jakarta: RajaGrafindo Persada. 
Susandi A. D. \& Widyawati, S. (2017). proses berpikir dalam memecahkan masalah logika matematika ditinjaudari gaya kognitif field independentdan field dependent numerical. matematika dan pendidikan matematika, 122.

Pratiwi. (2015). Pengaruh Tingkat Pendidikan, Perhatian Orang Tua, dan Minat Belajar Siswa Terhadap Prestasi Belajar Bahasa Indonesia Siswa SMK Kesehatan di Kota Tanggerang. Jurnal Pujangga, 1(2), 89-90.

widyaningrum. (2016). analisis kesulitan siswa dalam mengerjakan soal cerita matematika materi aritmatika sosial ditinjau dari gaya belajar siswa kelas VII Smp negeri 5 metro. iqra 1(2), 166-190.

Wijaya, W. (2001). Strategi Pembelajaran. Bandung: Prenda Media Group. 